PRODUCTION

ENGINEERING ARCHIVES
2015, Vol. 6, No 1, pp 39-44

ISSN 2353-5156

ISSN 2353-7779 (print version)

(online version)

Article history: $\quad$ Received: 29.01.2015

\title{
Microbial hazards reduction during creamy cream cheese production
}

\author{
Dorota Miarka $^{1}$, Joanna Żukowska ${ }^{1}$, Adam Siwek ${ }^{1}$, Joanna Nowacka ${ }^{2}$, Dorota Nowak ${ }^{3}$ \\ ${ }^{1}$ Institute of Food Technology and Gastronomy, The State Higher School of Computer Science \& Business Administration, Akademicka 14, \\ Lomza, Poland, e-mail: jzukowska@pwsip.edu.pl \\ ${ }^{2}$ SM Ostrowia \\ ${ }^{3}$ Institute of Food Engineering and Process Management, Warsaw University of Life Sciences, Nowoursynowska 166, Warsaw, Poland, e- \\ mail: dorota_nowak@sggw.pl
}

\begin{abstract}
The purpose of the work was to identify the hazards relevant to the production of safe food and to assess the effects of a possible infection. The paper presents the microbiological hazards that can occur throughout the production of creamy cream cheese and indicates the means to their minimization or elimination. The analysis of microbiological hazards showed that in the manufacturing process of the type of cheese mentioned, there are a few critical steps that should be specifically overseen. In order to acquire a high quality product it is important to monitor a quality of raw material, the parameters of pasteurization and souring, temperature of product packaging, storage conditions of the finished product and maintain hygiene throughout the production. The process of heat treatment, which is pasteurization, is a critical step (critical control points - CCP) for the whole process. Monitoring this stage and consistent adherence to Operational Pre-Condition Programs at the thermisation and centrifuging and later packaging, guarantees a safe product and its long shelf life.
\end{abstract}

Key words - food safety, quality of food, microbiological hazard

\section{Introduction}

Among numerous products made from milk, cheeses represent quite an extensive range. There are many types of cheeses which are divided in reference to a variety of milk, fat content, texture, production process and ripening time. In Poland, cheeses are divided according to the content of fat in dry mass into: cream full-fat cheeses with the content of fat not lower than $45 \%$, fat - $40 \%$, semi-fat $20 \%$ and skimmed cheeses containing lower than $10 \%$ fat. In other countries, there exists a variety of different standards which are connected with local traditions, climatic conditions and cheese production norms. Cheese textures depend on the content of water in them and the technological process which the cheese mass undergoes. Cheeses are divided into soft and hard varieties.

The aim of the paper is to analyze the possibility of occurrence of microbiological hazards at each stage of double-cream cheese production from milking and processing of the raw material through production and distribution of the finished product. An attempt will be made to identify hazard from the viewpoint of safe food production and assessment of the effects of its potential contamination.

\section{The levels of food safety}

The general principles and requirements of the food law were established by the EU Regulation No. 
178/2002 of January 28, 2002. Scientific foundations used for the establishment of the food law are based on the notion of risk and its analysis. The notion of risk is understood as the probability function of negative effects on human health and the severity of these effects as a result of a potential hazard. The hazard is, in turn, a biological, chemical or physical factor in food or feed or the state of food or feed which can cause negative effects on human health.

The target levels of food safety are defined at the country level. These are maximum frequencies of occurrence or concentration of the agents presenting food hazards at the time of product consumption. The proper levels of protection are the levels recognized by particular countries as appropriate ones for the establishment of sanitary and phyto-sanitary means to protect lives of people, animals and plants on their territories. These levels are established in reference to annual epidemiological reports which determine the number of cases of a particular disease, combination of hazards - a group of foodstuff and the reduction of cases of a particular disease. The target levels of food safety are closely connected with the target levels of hazards and critical levels established at the level of food manufacturers in compliance with principles of HACCP and Good Practices such as GAP, GVP, GHP, and GMP.

Every food manufacturer is legally obliged to collect and assess information related to hazards and conditions of their occurrence in order to decide which of them, due to their importance for the food safety, must be taken into consideration and controlled in the HACCP plan.

The group of legally established foodstuff microbiological criteria relevant to cheeses determine pathogenic bacteria dangerous to humans. These are Salmonella sp, Listeria monocytogenes, Staphylococcus aureus and Escherichia coli (KOWALIK J. 2011).

\section{The sources or reasons for microbi- ological hazards in a milk processing plant}

The hazard can come from the raw material, personnel, production halls, water, air, cleaning and disinfection procedures, additives and packaging (KOWALIK J. 2011).
The contamination of milk by original microflora is not high. It constitutes on average a few hundred of bacteria in cm3. The contamination of milk can happen even in the udder in case of a disease, while milking or any other sequential procedures (ZADERNOWSKI M.R. I WSP. 2008).

The development of bacteria in milk, which is inside a mammary gland and 2-3 hours after milking, is impeded by bacteriostatic and antibacterial natural substances that it contains. The natural bacteriostatic system is sufficient if microbiological contamination is not high.

The surface of a healthy human skin is covered with, first of all, Gram-positive spherical bacteria (cocci) and diphtheroid rods. These bacteria create a selective barrier which protects the skin against its colonisation by potential pathogenes.

The necessity to maintain an appropriate level of hand hygiene by food industry personnel results from their frequent direct contact with the processed stock as well as the finished product.

A milk processing plant, cold stores and production halls can be populated by Listeria monocytogenes. The areas where contamination can concentrate and then be introduced into the product are, first of all, all kinds of floors, especially in such places where water can accumulate, for instance, at a packing machine. It can also happen via aerosoles through the air or contact between people and equipment. Water is an essential raw material for almost all branches of food industries. It plays an important role in the milk industry where it is for the process of regeneration of milk powder for production of milk and fermented milk drinks, butter, soft cheeses, casein, and washing procedures (KOWALIK J. 2011; KRĘGIEL D. 2006).

Air presents the source of contamination in a milk processing plant, as it lends the environment for the transfer of bacteria between living organisms and inorganic matter. In production halls there is a typical saprophitic microflora: filamentous fungi of Aspergillus sp., Penicillium, Cladosporium, Rhizopus, Mucom, as well as bacteria of Micrococcus sp., Bacillus, Staphylococcus and other kinds specific to the production. Many factors influence the degree of microbiological contamination of the air in a plant (GUTAROWSKA B. 2011; KRĘGIEL D. 2006). The production activity of the personnel and the work of the equipment, which 
stimulates the airflow and maintains bio-aerosol, have a major impact on the higher concentration of bacteria in the air. It is estimated that more than $25 \%$ of bacteria present in the air comes from the human body.

Table 10.1. Microbiological pollution of indoor air in dairy plants

\begin{tabular}{|c|c|c|c|}
\hline $\begin{array}{l}\text { Type of plant / } \\
\text { production space }\end{array}$ & $\begin{array}{l}\text { Number of } \\
\text { bacterias } \\
{\left[\mathrm{jtk} / \mathrm{m}^{3}\right]}\end{array}$ & $\begin{array}{l}\text { Number of } \\
\text { fungus } \\
{\left[\mathrm{jtk} / \mathrm{m}^{3}\right]}\end{array}$ & $\begin{array}{l}\text { The predominant types } \\
\text { of microorganisms }\end{array}$ \\
\hline milk collection & $\begin{array}{l}2,2 \times 10^{2}- \\
5,5 \times 10^{3}\end{array}$ & $\begin{array}{l}1,1 \times 10^{2}- \\
7,4 \times 10^{3}\end{array}$ & $\begin{array}{l}\text { Micrococcus, Bacillus, } \\
\text { Cladosporium, } \\
\text { Penicillium, } \\
\text { Ulocladium, } \\
\text { Epicoccum }\end{array}$ \\
\hline packaging of milk & $\begin{array}{l}2,2 \times 10^{1}- \\
3,8 \times 10^{2}\end{array}$ & $\begin{array}{l}3,5 \times 10^{1}- \\
6,6 \times 10^{2}\end{array}$ & $\begin{array}{l}\text { Micrococcus, Bacillus, } \\
\text { Cladosporium, Penicil- } \\
\text { lium, }\end{array}$ \\
\hline $\begin{array}{l}\text { Production of } \\
\text { cottage cheese - } \\
\text { presses }\end{array}$ & $\begin{array}{l}2,2 \times 10^{2}- \\
3,0 \times 10^{3}\end{array}$ & $\begin{array}{l}8,0 \times 10^{1}- \\
6,3 \times 10^{3}\end{array}$ & $\begin{array}{l}\text { Micrococcus, Bacillus, } \\
\text { Cladosporium, } \\
\text { Penicillium, } \\
\text { Rhodotorula }\end{array}$ \\
\hline $\begin{array}{l}\text { Production of } \\
\text { cottage cheese } \\
\text { cooler }\end{array}$ & $\begin{array}{l}5,2 \times 10^{1}- \\
1,2 \times 10^{3}\end{array}$ & $\begin{array}{l}5,2 \times 10^{1}- \\
3,1 \times 10^{2}\end{array}$ & $\begin{array}{l}\text { Micrococcus,Bacillus, } \\
\text { Cladosporium, } \\
\text { Penicillium, } \\
\text { Rhodotorula }\end{array}$ \\
\hline $\begin{array}{l}\text { production of } \\
\text { yoghurt }\end{array}$ & $\begin{array}{l}2,6 \times 10^{1}- \\
3,9 \times 10^{3}\end{array}$ & $\begin{array}{l}4,6 \times 10^{1}- \\
3,6 \times 10^{3}\end{array}$ & $\begin{array}{l}\text { Micrococcus, Penicil- } \\
\text { lium, } \\
\text { Scopulariopsis }\end{array}$ \\
\hline $\begin{array}{l}\text { production of } \\
\text { homogenized } \\
\text { cheese }\end{array}$ & $\begin{array}{l}1,0 \times 10^{2}- \\
5,0 \times 10^{3}\end{array}$ & $\begin{array}{l}2,1 \times 10^{2}- \\
5,2 \times 10^{2}\end{array}$ & ns \\
\hline $\begin{array}{l}\text { fermented bevera- } \\
\text { ges }\end{array}$ & $2,6 \times 10^{1}$ & no in $50 \mathrm{l}$ & Bacillus \\
\hline $\begin{array}{l}\text { Production of } \\
\text { butter }\end{array}$ & $\begin{array}{l}5,6 \times 10^{1}- \\
6,6 \times 10^{2}\end{array}$ & $\begin{array}{l}5,3 \times 10^{1}- \\
3,1 \times 10^{2}\end{array}$ & $\begin{array}{l}\text { Micrococcus, Bacillus, } \\
\text { Acremonium, } \\
\text { Aspergillus, }\end{array}$ \\
\hline $\begin{array}{l}\text { warehouses pack- } \\
\text { aging, dunks, } \\
\text { loose components }\end{array}$ & $\begin{array}{l}1,2 \times 10^{3}- \\
4,4 \times 10^{3}\end{array}$ & $\begin{array}{l}3,6 \times 10^{2}- \\
4,8 \times 10^{3}\end{array}$ & $\begin{array}{l}\text { Micrococcus, Bacillus, } \\
\text { Cladosporium, } \\
\text { Penicillium, } \\
\text { Aspergillus }\end{array}$ \\
\hline
\end{tabular}

ns- not studied

Source: national research Merck

There are many washing procedures in milk processing. The quality of washing procedure depends on the temperature, time and physical actions of washing solutions. Lowering the parameters of one agent requires the increase of the other agents.

Different kinds of additives are used in technological processes of milk products beginning with starter cultures for milk acidification and ending with flavouring ingredients such as spices or salt. The microbiological quality of the used additives in terms of number as well as kinds of present bacteria is extremely varied (BRUŻEWICZ, A. MALICKI A. 2007).

\section{Good Hygiene Practices in a company (Pre-Condition Programs)}

While making a list of microbiological threats, quite a number of them have been identified (KoWALIK J. 2011). However, ensuring the proper technical, organizational and hygienic standards before taking actions related to production and distribution, guarantees the healthiest quality of the product.

Maintaining high hygienic standards within the complete process of obtaining milk, which ensures its quality, is closely connected with the fulfilment of the proper requirements.

Good Hygiene Practice (GHP) in a company is a definition which comprises a few areas closely integrated and directed at the achievement of the optimum goal, which is food safety. The requirements of GHP are often defined by Pre-Condition Programs and cover the following (ZIAJKA S., TARCZYŃSKA S. 2011):

- location, surrounding and infrastructure of a company

- provision of the appropriate amount of the necessary equipment and machines (especially cooling devices),

- careful choice of raw materials and feedstocks,

- systematic washing with the use of proper equipment and chemicals,

- provision in water of the proper quality and waste control,

- protection against pests,

- hygiene of the personnel and personnel training,

- proper storage of foodstaff. 


\section{Production stages of cream cheese in reference to minimalization or elimina- tion of potential microbiological hazards (Operational Pre-Condition Programs)}

\subsection{Production technology of cream cheese}

Cream cheese is fat cheese of the cottage cheese variety and is called cream cheese or double cream cheese.

The raw material for cheese is cow milk which is standardized to $12 \%$ of fat content. The cream flows to a separator where it is heated to $55^{\circ} \mathrm{C}$, homogenized and cooled. The cream at the coagulation temperature at $23-24^{\circ} \mathrm{C}$ is directed to a fermentation tank. After adding milk bacterial cultures and rennet the process of coagulation takes place, until the product reaches $\mathrm{pH}$ 4,9 - 4,7. The curd is then centrifuged and is cooled to a temperature of $8^{\circ} \mathrm{C}$ in order to slow down the activity of bacterial cultures. After that the curd goes to another separator where it is heated to $80^{\circ} \mathrm{C}$. The separator is set to obtain the dry mass of the product at $35 \%$, and the amount of salt at $0,8 \%$ is added. On coming out of the separator the product goes to the agitator/mixer where spices are added. In order to improve the texture of the product stabilizers can be used. The product is packed hot into plastic containers. The cooling of the product takes place in refrigerated storage not exceeding the cooling point of $8^{\circ} \mathrm{C}$. The storage and distribution should not break the cold chain (TEAM OF DAIRY. 2012).

\subsection{Hazards and means of control at particular stages of the process, collection and storage of raw milk}

There is a risk of getting bacterial pathogens into milk processing at this stage as raw milk can occasionally contain them. However, the hazard can be controlled by supervising the construction of the milk processing plant (TEAM OF MP „OSTROWIA”. 2011).

The means of control over such a risk are the predefined conditions of storage: the temperature below $5^{\circ} \mathrm{C}$ and the period of stay in a silo before pasteurization limited to a minimum (TEAM OF DAIRY. 2012).

Centrifuging and standardization of fat: the milk is heated to $50-55^{\circ} \mathrm{C}$ and purified. Standardization of whole milk takes place by adding to it pasteurized cream to obtain fat content at $12,0 \%$.

The means of control at this stage are adherence to the centrifuging temperature parameters, to control the lipase activity and time limitation between standardization and pasteurization.

Pasteurization standardized cream is pasteurized at $74^{\circ} \mathrm{C} \pm 2^{\circ} \mathrm{C} / 180$ sec. Operational Pre-Condition Programs at this stage ensure that the cream is heated to $72^{\circ} \mathrm{C} / 15 \mathrm{sec}$. The means of control over the risks are: the fulfilment of the requirements of GHP in reference to equipment and machines.

Cooling: Pasteurized cream is cooled to the max temperature of $5^{\circ} \mathrm{C}$. The hazard at this stage can be a secondary contamination or the impossibility of obtaining the appropriate temperature for the cooling of the curd. The means of control are the proper washing and rinsing procedures and ensuring the proper functioning of the device.

Heating: The cream is heated up to $55^{\circ} \mathrm{C}$. The hazard at this stage can be a secondary contamination or the impossibility of obtaining the appropriate temperature for the cooling of the curd. The means of control are proper washing and rinsing procedures and ensuring the proper functioning of the device; monitoring of the temperature.

Homogenization: The hazard at this stage can be a secondary contamination or the impossibility of obtaining the appropriate temperature for the cooling of the curd. The means of control are proper washing and rinsing procedures and ensuring the proper functioning of the device; monitoring of the temperature.

Cooling: The hazard at this stage can be a secondary contamination or the impossibility of obtaining the appropriate temperature for the cooling of the curd. The means of control are proper washing and rinsing procedures and ensuring the proper functioning of the device; monitoring of the temperature.

Filling of the fermentation tank with pasteurized cream poses two potential hazards: the improper temperature of the cream - either too cold or too hot for the growth of the acidified culture and the secondary contamination from the improperly cleaned cables and surfaces. Operational Pre-Condition Programs applied at this stage are the proper arrangements of the work of the pasteurizer. 
Flavouring: The hazards which appear at this stage are the microbiological contamination with the stock culture and rennet or contamination through additives or their improper dosage.

The means of control over the hazards are ensuring of the sufficient quality of the additives through specification and audit at the supplier's as well as implementation of the adequate working procedures for the hygienic treatment of the additives and their proper dosage.

Coagulation is connected with the hazard of contamination of the pasteurized cream by pathogenic bacteria either due to the impossibility of close control of the previous stages of the process or the secondary contamination from the equipment or the environment of the company. The means of control over the risk are: adherence to the defined and planned washing procedures of the equipment as well as the area of the plant; the use of the active stock culture added in a corresponding dose and chosen in such a way that it is resistant to local bacteriophages; establishing hygienic barriers to avoid cross-contamination; monitoring the speed and level of acidity development alongside a withdrawal of the batches with the exceeding parameters.

Cooling: The hazard at this stage can be a secondary contamination or the impossibility of obtaining the appropriate temperature for the cooling of the curd. The means of control are proper washing and rinsing procedures and ensuring the proper functioning of the device; monitoring of the temperature.

Thermisation: The hazard at this stage can be a secondary contamination from the improperly washed device. The means of control are proper washing and rinsing procedures.

Centrifuging: The hazard at this stage can be a secondary contamination from the improperly washed device. The means of control are proper washing and rinsing procedures.

Flavouring: Operational Pre-Condition Programs comprises specification and audit of the spices at the supplier's to reduce to a minimum their levels of impurity; proper storage of flavourings as well as hygienic treatment of the additives on their way to the agitator and while adding them; implementation of the proper working procedures ensuring their proper dosage.
Agitating: The hazard at this stage can be a secondary contamination from the improperly washed device. The means of control are proper washing and rinsing procedures.

Packing: The finished product is threatened by the secondary contamination as well as air pollutants while unit batching. The means of control are the proper washing and rinsing procedures and ensuring the packaging materials are properly stored before use, assuming that the packaging manufacturer belongs to the authorized suppliers adhering to high hygienic standards.

Cooling: The hazard at this stage can be posed by the impossibility of cooling the product to the appropriate temperature to minimize the bacterial growth which can spoil the product. The means of control are monitoring the cooling temperature and ensuring the proper functioning of the cooling device.

Storage: The improper storage temperature is a hazard to the product. Ensuring the proper storage temperature and securing the product against all forms of contamination during the storage period are the means of control.

Distribution: The hazard at this stage is breaking the cold chain.

\section{Assessment of the Threat Scale}

After carrying out the analysis, it is necessary to state that all the analyzed pathogenes may cause inflammatory states of the mammary gland in cows and, as a result, also appear in raw milk. Pasteurization is the main process during the production of cream cheese which influences microbiological security of the finished product. The aforementioned pathogenes may appear in the finished product due to crosscontamination (TEAM OF DAIRY. 2011).

Taking into consideration the acidity $\mathrm{pH}<5,0$ of the finished product, the use of thermisation in combination with a high temperature of centrifuging of the curd as well as packing the product hot and at the same time the low number of the pathogenic colonies discussed in the present article and the dangerous consequences of their presence in food to human health, their appearance in the finished product can be defined as a medium threat (TEAM OF DAIRY. 2011). 


\section{Evaluation of the Threat to the Con- sumer's Health}

A single consumption of cream cheese or double cream cheese is $60 \mathrm{~g}$. Half of the Polish population buys cheese and cheese spreads at least once a week. Taking into consideration that the symptoms of an illness can manifest at MID $102 \mathrm{jtk} / \mathrm{g}$ of the product, in a usual portion of $60 \mathrm{~g}$ the number of cells will constitute 6 x 103 jtk (TEAM OF HACCP. 2012). Cream cheese can cause food poisoning. Making a full list of microbiological threats makes it possible to choose proper preventive measures and means of control over specifically identified threats which can appear in the production process.

\section{Summary and conclusions}

The analysis of microbiological hazards in the production process of double cream cheese has shown that there are stages which should be closely supervised so that the finished product is safe. Monitoring the quality of raw material, pasteurization parameters, acidification process, packing temperature, storage conditions of the finished product, and proper hygiene in the whole production cycle are extremely important.

The process of heat treatment, which is pasteurization, is the stage where the elimination of the pathogens essential for the health safety of the product takes place on condition that temperature parameters and time of holdover in the appropriate temperature are critical points to the whole process (CCP). Monitoring this stage and consistent adherence to Operational PreCondition Programs at the thermisation and centrifuging and later packaging, guarantees a safe product and its long shelf life.

The analysis of hazards has also shown the vital role of a person in the whole process. It indicates the huge need of trainings for the personnel engaged in food production.

Adherence to the requirements of Good Hygienic Practice and the implementation of HACCP systems at each stage of the food chain, which means by each manufacturer co-operating with food industries from primary production to manufacturers of additives and packaging and close co-operation with all links along- side governmental food inspections positively influences the production of safe food.

\section{Literature}

1. BRUŻEWICZ, A. MALICKI A. 2007. Microbiological status of selected spices and survival of microorganisms in them. "Żywność. Nauka. Technologia. Jakość” 4(53), 99-108.

2. KOWALIK J. 2011. Threats: Threats microbiology in the dairy industry. Forum Mleczarskie Biznes 2/2011 http://www.forummleczarskie.pl/ (05.03.2012)

3. KRĘGIEL D. 2006. Microbial contamination of air technology hall and the quality of manufactured packaging. “Żywność. Nauka. Technologia. Jakość” 1 (46), 52-5

4. TEAm Of DAIRY. 2011. Sanitary Hygienic Code. MP „Ostrowia” in Ostrów Mazowiecka. Ed. 6 of 16.09.2011r.

5. TEAM OF DAIRY. 2012. Technology Manual IT / 06 Version 4 of 18.01.2012. MP „Ostrowia” in Ostrów Mazowiecka

6. TEAM OF HACCP. 2012. The HACCP plan no. 2 for cream cheese cream „Ostrowia” ed. 9 of 16.01.2012r. MP „Ostrowia” in Ostrów Mazowiecka

7. TEAM OF MP „OSTROWIA”. 2011. Quality specification DT / 01. Cream cheese cream ed. 6 of 19.10.2011 r. Milk Plant „Ostrowia” in Ostrów Mazowiecka

8. ZADERNOWSKI, M.R., ZADERNOWSKA A., OBIEDZIŃSKI, M., ZADERNOWSKI. R. 2008. HACCP Catalog of Biological physical and Chemical Hazards. Gdańsk ODDK.

9. ZIAJKA, S., TARCZYŃSKA, S. 2011. Trends in food safety management. Training materials. Olsztyn. UWM. 